\title{
Associations Between Faculty Publishing Output and Opinions Regarding Student Library Skills
}

\section{Marcia L. Boosinger}

This is a study of associations between faculty publishing output as measured by citation counts for academic departments and faculty instructional practices and their perceptions of student needs and abilities related to the library. These associations were measured by faculty responses to selected questions from a survey regarding the importance of library skills. Positive association exists between publishing output and whether or not classes taught require library use, the frequency of required library tours, the degree to which library tours contribute to student library abilities, and the ranking of graduate student library abilities. These results have planning and instructional implications for bibliographic instruction librarians.

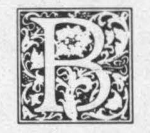

ibliographic instruction librarians have long viewed the cooperation of instructional faculty as a vital factor in student acquisition of library skills. ${ }^{1}$ While librarians have conducted numerous surveys of faculty attitudes toward libraries and toward student need for library skills instruction, resulting studies have been primarily descriptive in nature. ${ }^{2}$ Very few studies have associated faculty attitudes toward student library skills with additional variables such as academic rank, tenure status, teaching experience, discipline, gender, age, teaching style, personal library use patterns, or average class size. ${ }^{3}$

The method of this exploratory study goes beyond the presentation of descriptive statistics. The purpose is to test hypotheses of association between survey responses and one additional variable, departmental publishing output as measured by number of journal articles produced. Determining if external variables that are related to departmental attitudes toward student library skills exist could offer bibliographic instruction librarians a better understanding of their teaching colleagues. Clearly, knowledge of each faculty member's personal research interests and constraints would be desirable. However, it may not be possible for BI librarians to be familiar with all faculty members and their class needs. Instead a degree of familiarity with each department may be all that is feasible. For example, are faculty from several departments engaged in teaching interdisciplinary courses that require a particular type of library use and instruction? Does pressure to publish within a particular department influence the attitudes of its faculty toward library skills acquisition? Do faculty in scientific disciplines heavily involved in graduate education and relying on journals and technical reports have library instruction needs different from faculty in bookoriented disciplines supporting chiefly undergraduate programs? Statistically reliable answers to these and other ques-

Marcia L. Boosinger is the Bibliographic Instruction Librarian at the Ralph Brown Draughon Library of Auburn University, Auburn, AL 36849-5606. The author gratefully acknowledges the invaluable assistance of Kevin L. Cook, Microforms and Documents Reference Librarian, Ralph Brown Draughon Library, Auburn University. 
tions regarding faculty instructional practices and perceptions related to library use instruction may help librarians develop effective strategies and materials for instructing various user groups involved in particular disciplines.

\section{BACKGROUND}

The literature concerning faculty practices and perceptions regarding student library skills falls into two general categories: discussions of portions of user surveys that measure the practices and perceptions of faculty regarding student library skills in the context of other issues and entire studies that describe such practices and perceptions as they relate specifically to library skills.

An example of the former is a DePauw University Libraries self-study that examined the entire range of library resources and services, including library skills instruction. ${ }^{4}$ The second category, studies focusing solely on faculty opinion regarding library skills, has as an important model the 1973 study by John Lubans and others at the University of Colorado as part of a Council on Library Resources-National Endowment for the Humanities-sponsored project, "Program to Improve and Increase Student and Faculty Involvement in Library Use. " Investigators surveyed the history and economics faculty and a random sample of other teaching faculty concerning undergraduate library skills. Questions included a rating of students' abilities to make use of library resources for research and term papers, student knowledge of appropriate resources to use when writing term papers, types of assignments made which require student use of library resources, reasons for not making assignments requiring library use, responsibility for explaining indexes, bibliographies, and other reference sources of a specific field, and relative effectiveness of types of formal library instruction. Lubans found that faculty thought few students have adequate library skills. Faculty believe that formal library use instruction of some sort, provided by librarians, teaching faculty, or both as a team, is a key factor in improving and increasing students' use of library resources.
A few studies outside these two categories compare similar survey data with additional variables. In 1989, librarians at Iowa State University conducted a study of faculty practices and perceptions regarding a required library skills course. Investigators concluded that faculty realized the need for the required library instruction course. While rank and type of appointment were not related to responses, faculty support for library instruction varied among colleges surveyed with the colleges of family and consumer sciences, education, agriculture, and engineering showing the strongest support, while the colleges of sciences and humanities, business, and design exhibited less support. Noticeable differences existed between responses from faculty who required library research from students and those who did not have such a requirement. Faculty who gave research assignments were more likely to think that students do not have the skills to do library research, less likely to think that they themselves needed to teach library skills, and more likely to think that the required library skills course should continue. ${ }^{6}$

Hardesty associated demographic characteristics of classroom instructors such as age, tenure status, discipline, academic rank, sex, highest degree, and teaching experience with responses to a 30 -item questionnaire. ${ }^{7}$ He used the responses from over 200 faculty members at four Indiana colleges to construct a scale designed to measure attitudes of undergraduate classroom instructors toward the library's role in undergraduate education. He found significant differences between the attitudes expressed by faculty at the various institutions about the role of the library in undergraduate education and concluded that the "educational atmosphere" of an institution can shape instructor attitudes toward this role.

A survey at California State University, Long Beach, in 1984 measured many of the same perceptions and practices as Lubans' initial Colorado survey. ${ }^{8}$ Three hundred and one faculty members responded to questions concerning what types of library instruction they employed, why they did not avail themselves of the instruction offered in the library (if they did 
not), how they believed their students learned to use the library, and what their opinions of students' abilities to do library research were. The study associated responses to questions regarding practices and perceptions of library use instruction with demographic characteristics of faculty (rank, tenure, full- versus part-time status, sex, and satisfaction with the library), and with "professional factors" (the faculty member's own method of learning to use the library, frequency of library use, length of service at that university, and faculty opinion of student research abilities). Most important to the present study, the Cal State Long Beach study compared faculty responses regarding student library use to their publishing histories. Of the faculty requiring their students to attend library use instruction, $70 \%$ had published within the last year compared with $57 \%$ of all respondents. Thirty-eight percent of those who last published five or more years ago required no library use instruction; this was true of only $29 \%$ of all respondents. The authors concluded that "a current publishing history often characterized the faculty members who requested student attendance at library-initiated lectures."'9

\section{METHODOLOGY}

This study was conducted at Auburn University, a state institution with an enrollment of approximately 21,000 students and 1,100 full-time faculty members organized administratively into thirteen colleges or schools and sixty-four departments. While maintaining the traditional land-grant emphasis on agriculture and engineering, Auburn grants baccalaureate degrees in 138 fields, master's degrees in sixty fields, and doctoral degrees in thirtyeight areas. ${ }^{10}$

Auburn University Libraries consist of the main library, branch libraries at the School of Architecture and the College of Veterinary Medicine, and a small reading room in a classroom building. The libraries have a faculty of fifty-one librarians, a staff of three archivists, two automation professionals, and ninety-six support persons and paraprofessionals, and holdings of over 1.6 million volumes. A bibliographic instruction librarian coor- dinates instructional activities that are shared among seven public service departments. The twenty-three librarians in these departments instructed 7,057 users in 369 sessions during fiscal year 1988-89.

Two methodological considerations existed at the beginning of this study: measuring faculty publishing output and measuring faculty practices and perceptions regarding student library skills. The literature surrounding both publishing output and student library skills suggested courses of action regarding these considerations.

"Of the faculty requiring their students to attend library use instruction, 70 percent had published within the last year compared with 57 percent of all respondents."'

Researchers in the social sciences and sciences and academic administrators have used publication counts to assess faculty publishing output for many years, with the belief that it is possible to evaluate faculty performance at least partially in terms of numbers of publications. ${ }^{11}$ They have used various methods of obtaining publication counts, including the use of interviews; vitae; self-reported data, often from surveys; and counts from indexes and databases such as Chemical Abstracts, $E R I C$, and the Institute for Scientific Information (ISI) products. ${ }^{12}$ Researchers have found it relatively simple to obtain "straight counts" of faculty publications using the Source and Corporate Indexes of these ISI citation indexes. ${ }^{13}$

In this study, the operational definition of publishing output is the total count of journal articles attributed to an Auburn University department in Arts and Humanities Citation Index, Social Sciences Citation Index, and Science Citation Index. The investigator recorded publication counts for any faculty member from instructor to full professor, excluding adjunct and emeritus appointments, from the Corporate Indexes Geographic Sections, of the three ISI citation indexes for 1985, 1986, 1987, and the first eight months of 1988 . Verifi- 
cation of individual faculty names in the 1985 through 1988 issues of the Auburn University Bulletin or the campus telephone directory was necessary because the citation indexes often combined publications of Auburn University authors and those of the separate but related Auburn University at Montgomery campus. Finally, the investigator counted and totalled publications for individual faculty members by department across the three citation indexes for the three years and eight months examined.

\section{"In all, the survey reached 1,599 fac- ulty members and graduate teaching assistants, and 551 surveys, or 34.5 percent were returned."'}

This study used an instrument developed by the User Education Committee of the General Libraries at the University of Texas at Austin. The Committee administered the "Survey of Faculty Opinion Regarding the Importance of Student Library Skills" to the UT-Austin faculty in 1975 in order to gauge faculty attitudes regarding library skills instruction and to determine departmental interest in bibliographic instruction. ${ }^{14}$ Since that time, the Policy and Planning Committee of the Bibliographic Instruction Section of ACRL has cited this instrument as an excellent example of a BI needs assessment instrument. ${ }^{15}$ Furthermore, Virginia Tiefel has recognized the UT-Austin study and its associated surveys as models of the delineation of the necessary steps and processes involved in developing a comprehensive BI program. ${ }^{16}$ Universities such as Texas Tech have used the study, particularly the faculty survey portion, to survey faculty and establish or change their BI programs. ${ }^{17}$ Jane I. Thesing has recommended the study as a tool for developing $a^{\text {" }}$ market audit" that will facilitate the development of a marketing approach to an academic library BI program. ${ }^{18}$

Taking these recommendations into consideration, Auburn University Libraries obtained permission to use the fac- ulty survey portion of the 1975 UT-Austin instrument for purposes of gathering information regarding faculty opinions related to library skills acquisition. The investigator sent the UT-Austin survey to all full-time and part-time teaching faculty, including instructors and graduate teaching assistants in January 1988, using a mailing list prepared by the university's Office of Institutional Analysis. In all, the survey reached 1,599 faculty members and graduate teaching assistants, and 551 surveys, or $34.5 \%$, were returned. The returns represented responses from $40.7 \%$ of the full professors, $41.1 \%$ of the associate professors, $40.2 \%$ of the assistant professors, $51.4 \%$ of the instructors, and $19.4 \%$ of the graduate teaching assistants. Though the survey response rate was not exceptionally high, comparison of faculty publishing output at the departmental level and survey responses should reduce the effect of the lower-than-expected response rate. The investigator tabulated responses to survey questions using Lotus 1-2-3.

Using the frequency procedure available with SAS software for the personal computer to analyze data, the investigator compared these survey responses with departmental publishing output determined from citation index publication counts, and examined two measures of association: Kendall's tau-b to measure association between the ordinal-level variables, and the chi-square test of association to measure association found in one yesor-no question. In this question, collapsed departmental publishing output data were grouped into categories of high, medium, or low publication frequency in relation to the number of publications of the most productive department. Figure 1 shows these frequencies and categories. Because each institution and library system is unique, the investigator made little attempt to generalize conclusions to other institutions.

\section{RESULTS AND DISCUSSION}

Questions from the UT-Austin instrument used in the Auburn survey and considered in this paper form two categories: faculty instructional practices as they re- 


\section{Low Publishing Output}

Architecture, Building Science, Geography, Industrial Design, Music, Nursing, Theatre; Vocational and Adult Education

Art, Veterinary Medicine Administration

Radiology, Textile Engineering

Aerospace Engineering; Marketing and Transportation

Computer Science and Engineering

Communication Disorders, Consumer Affairs, Pharmacy Care Systems

Communication, Religion

Clinical Pharmacy, Counseling Psychology, Journalism

Curriculum and Teaching; Family and Child Development

Counselor Education

Math (Foundations and Topology)

Educational Foundations, Leadership, and Technology; Pharmacy

Accounting; Anatomy and Histology

Rehabilitation and Special Education

Geology, Management, Mechanical Engineering; Nutrition and Foods

Sociology

Electrical Engineering; Physical Education and Recreation

Large Animal Surgery and Medicine; Philosophy

Industrial Engineering

Agricultural Engineering, Fisheries

Poultry Science

\section{Medium Publishing Output}

\section{Political Science}

Civil Engineering

Agronomy and Soils; Chemical Engineering

Scott-Ritchey Foundation

Physics; Physiology and Pharmacology; Small Animal Surgery and Medicine

Agricultural Economics and Rural Sociology; Forestry, Pharmacal Science

Animal and Dairy Science

Zoology

Math (Algebra and Combinatorics)

Horticulture

History

Foreign Languages

Economics

\section{High Publishing Output}

Botany and Microbiology; Plant Pathology

Chemistry

Psychology

English

Pathobiology

FIGURE 1

Departmental Publishing Output 
late to the library, and faculty perceptions of student library skills and needs. Survey questions concerning instructional practices asked whether faculty teach courses requiring library use, the frequency of required library tours, how frequently they require library tours, and how frequently they discuss indexes and bibliographies in class. Questions concerning perceptions of student library skills and needs dealt with faculty beliefs about the contribution of library tours to student library use abilities, as well as with overall undergraduate and graduate student abilities to use the library for research. A copy of the survey questions considered in this study is available from the investigator.

The two research problems follow. The comparison of departmental publishing output with specific survey questions form the six related hypotheses.

\section{Research Problem 1}

Is there association between departmental publishing output and faculty members' instructional practices related to the library?

$\mathrm{H}_{1}$ : There is an association between departmental publishing output and whether faculty often teach courses that require student use of the library.

$\mathrm{H}_{2}$ : There is an association between departmental publishing output and the frequency with which faculty require their students to take a library tour.

$\mathrm{H}_{3}$ : There is an association between departmental publishing output and the frequency with which faculty members explain to their classes the indexes and bibliographies in their fields.

Each of these three hypotheses is accepted. (See figure 2.) Faculty in productive departments more often teach courses that require student use of the library $\left(X^{2}=32.234, \mathrm{df}=2, \mathrm{p}<.05\right)$ and more often require their students to take a library tour $(\mathrm{t}=.124, \mathrm{p}=<.01)$, than do their colleagues from less productive departments. However, they less frequently explain indexes and bibliographies to their students than do their colleagues from departments with lesser publishing outputs $(\mathrm{t}=-.083, \mathrm{p}<.01)$.

While faculty in productive departments apparently see the importance of an introduction to, and use of, the library for their courses, they do not become actively involved in introducing library resources, for example, by presenting sources in class or by participating with a librarian during a library instruction session. The fact that they more frequently teach courses that require student use of the library may be related to the requirements of the specific courses taught, as much as to any strong feeling the faculty or productive department may have about the use of the library. While such faculty also are more likely to require a library tour for their students, they may be taking a passive role in the library instruction process. Most faculty who request instructional sessions at Auburn University Libraries rely almost exclusively on those developed and presented by librarians. Evidence of faculty passivity exists in the substantial number of faculty members contacted by librarians in order to initiate instructional sessions.

The negative association between departmental publishing output and $\mathrm{H}_{3}$, explanation of reference sources by faculty to classes, demonstrates even more explicitly the passiveness of productive faculty involvement with library instruction. While faculty from productive departments are quite willing to require library use and tours, they are less likely than faculty from less productive departments to explain sources in their fields to students.

Reasons for this apparent passivity may be many. Productive faculty may be aware, from contact with librarians in the course of their own research, that bibliographic instruction is available from librarians who are knowledgeable and willing to teach their students how to use the library for research. They may view library skills instruction as out of their purview as faculty members, or they may not view it as important enough to merit use of class time. Perhaps their teaching, research, and publishing loads are too great to consider the addition of yet another task that might be better left to librarians or even to students' independent investigation. Reasons for such passivity bear further study.

\section{Research Problem 2}

Is there association between depart- 
Hypothesis

$\mathrm{H}_{1}$ There is an association between publishing output and whether faculty often teach courses that require student use of the library.
Results
$X^{2}=32.234$
$\mathrm{df}=2$
$p<.05$
$N=551$
$t=.124$
$p<.01$
$N=535$

$$
\begin{gathered}
t=-.083 \\
p<.01 \\
N=357
\end{gathered}
$$

$\mathrm{H}_{2}$ There is an association between publishing output and the frequency with which faculty require their students to take a library tour.

$\mathrm{H}_{3}$ There is an association between publishing output and the frequency with which faculty explain to their classes the indexes and bibliographies in their fields.

FIGURE 2

Association between Faculty Publishing Output and Faculty Members' Instructional Practices Related to the Library

mental publishing output and faculty perceptions of the students regarding library skills and needs?

$\mathrm{H}_{4}$ : There is an association between departmental publishing output and the degree to which faculty members believe library tours contribute to students' ability to use the library for term papers, research, etc.

$\mathrm{H}_{5}$ :There is an association between departmental publishing, output and faculty ranking of undergraduate students' ability to use the library resources for term papers and research.

$\mathrm{H}_{6}$ : There is an association between departmental publishing output and faculty ranking of undergraduate students' ability to use the library resources for term papers and research.

Two of these three hypotheses, $\mathrm{H}_{4}$ and $\mathrm{H}_{6}$, are accepted at levels of $\mathrm{p}<.01$ and $\mathrm{p}<.05$, while one, $\mathrm{H}_{5}$, is rejected $(\mathrm{t}=.036$, $\mathrm{p}>.1$ ). (See figure 3.)

Faculty in productive departments are more likely than faculty from less productive departments to believe that library tours contribute to a student's ability to use the library for term papers and research $(t=.104, p<.01)$. They are less likely than their peers associated with less productive departments to rank highly graduate students' ability to use library resources for term papers and research $(\mathrm{t}=-.088, \mathrm{p}<.05)$. However, there is no statistically significant difference between the opinions of faculty from more productive or less productive departments regarding the ranking of undergraduate stu- dents' ability to use library resources for term papers and research $(\mathrm{t}=.036, \mathrm{p}>.1)$.

Because faculty from productive departments are more likely to require library tours of their students, as seen in $\mathrm{H}_{2}$, presumably they might be more likely than faculty from less productive departments to believe that such tours contribute to the students' ability to use the library. Whether the practice of requiring such tours preceded the perception of their success is impossible to determine, but a cause-and-effect relationship between the requirement and perception may exist.

There is no significant difference between faculty in productive and those in less productive departments in their perception of undergraduate ability to use the library for term papers and research. However, with the acceptance of $\mathrm{H}_{6}$, it appears that faculty from more productive departments believe graduate students are less likely to be able to use library resources for research. This may stem in part from the probable close contact with large numbers of graduate students associated with productive programs in productive departments. It is this familiarity that may provide the reason for low rankings of graduate student library abilities. Faculty from less productive departments may attract fewer graduate students and may have less well-formed opinions about graduate student library skills because of less contact with the group as a whole.

These results show that this study adds a dimension to previous user studies or bibliographic instruction needs assess- 


\section{Hypothesis}

Results

$\mathrm{H}_{4}$ There is an association between publishing output and the degree to which faculty members believe library tours contribute to a student's ability to use the library for term papers, research, etc.

$\mathrm{H}_{5}$ There is an association between publishing output and faculty ranking of undergraduate students ability to use the library resources for term papers, research, etc.

$\mathrm{H}_{6}$ There is an association between publishing output and faculty ranking of graduate students' ability to use the library resources for term papers, research, etc.

FIGURE 3

Association between Faculty Publishing Output and Faculty Perceptions of Students Related to Library Skills and Needs

ments by introducing an additional variable, departmental publishing output, to be compared with faculty practices and perceptions regarding student library skills. Departmental publishing output is positively associated with four survey questions dealing with faculty instructional practices and perceptions of student abilities related to the library: (1) whether faculty teach courses that require student library use; (2) the frequency with which they require students to take a library tour; (3) the degree to which faculty believe library tours contribute to a student's ability to use library resources; and (4) the faculty ranking of graduate students' ability to use library resources. Departmental publishing output is negatively associated with only one survey question, concerning the frequency with which faculty in productive departments explain indexes and bibliographies to their classes. Only one of the questions considered, that dealing with faculty ranking of undergraduate abilities to use library resources for term papers and research, failed to show association with departmental publishing output.

From these associations, BI librarians

\footnotetext{
"It may be necessary for BI librarians to promote instruction tailored to the needs of a particular class or assignment."
}

can begin to list considerations regarding the instructional needs of faculty from productive departments. Because productive faculty are more likely to teach courses that require student use of the library, BI librarians will want to be aware of faculty assignments that would lend themselves to course-related instruction. Productive faculty members already hold lower opinions about the abilities of graduate students to do library research; therefore, BI librarians may have little difficulty convincing such faculty of the need for indepth library instruction on the graduate level. However, while productive faculty are likely to require tours of the library, possibly because they are also more likely to believe that such tours contribute to students' ability to use the library for research, it may be necessary for BI librarians to promote the idea that instruction tailored to the needs of a particular class or assignment, rather than simply a tour, might prove to be more satisfactory to the faculty members involved because it could be more beneficial to their students. Because productive faculty are less likely to explain indexes and bibliographies to their classes, BI librarians may find it necessary to gear their instruction to the class's meager knowledge of library research tools.

\section{SUGGESTIONS FOR FURTHER RESEARCH}

Beyond the traditional classroom setting are new challenges for BI librarians. These include diverse faculty members united 
by innovative teaching techniques, uniquely structured subject material, and shared teaching responsibilities in interdisciplinary studies as well as examples of team teaching between departments within colleges or schools. To begin to study these new constituencies, investigators should develop a list of additional variables related to faculty practices and perceptions that bear further research on the departmental level. Variables to be analyzed might be taken from previous studies, such as Hardesty's study of the four Indiana colleges as well as the studies at Iowa State and Cal State Long Beach, where some descriptive statistical evidence of relationships between variables exhibited by faculty members and their practices and perceptions regarding student library skills already has been determined. Institution, college, discipline, library-related course requirements, and personal library use patterns are a few of the previously studied variables that might form an initial list of items for consideration.

"Many more aspects of faculty instructional practices and perceptions of student ability related to the library could be studied with a survey instrument designed specifically to obtain this information."

Many more aspects of faculty instructional practices and perceptions of student ability related to the library could be studied with a survey instrument designed specifically to obtain this information. This instrument, the second step in the course of further research, would ask more precise questions, require more detailed answers, and provide more ranked responses to scaled questions regarding faculty practices and perceptions. The investigator could determine more accurate and precise measures of practice and perception, and the data could be analyzed at least at the ordinal level. Such an instrument should contain more questions directly applicable to faculty instructional practices and perceptions related to the li- brary than this investigator asked using the UT-Austin study. The list of additional questions about faculty instructional practices and perceptions must be greatly expanded within such an instrument in order to determine faculty opinion about a broader range of library-skills instruction issues as they relate to variables being studied. Exactly what types of class sessions do the responding faculty who exhibit a certain characteristic require of their students-those solicited by faculty members and prepared by librarian subject specialists expressly for the library resource needs of an individual class, or general orientation tours without actual instruction? What specific perceptions do such faculty members have about the contributions of library instructional sessions to student ability to use the library? Are students making use of a variety of sources and are those sources appropriate and pertinent to the assignment?

A possibility for further research combining the variables of publishing output and faculty instructional practices and perceptions regarding student library needs would be the developing of an ordinal scale to measure active versus passive participation in the library skills acquisition process of faculty from both more productive and less productive departments, and the impact of levels of such participation on faculty perceptions of student performance of assignments requiring use of the library. The scale could include items measuring faculty attendance at library instruction classes, faculty participation during such classes, faculty reinforcement of library instruction in class discussion, assignments geared to use of library resources utilizing a defined research process or search strategy, and actual student performance on such assignments.

\footnotetext{
"Investigators need to develop an instrument to determine the relative weights of seemingly unrelated faculty characteristics that impact practices and perceptions regarding student library skills."
} 
Finally, investigators will need to develop an appropriate instrument to conduct an additional study of such variables in combination in order to determine the relative weights of seemingly unrelated faculty characteristics that impact on faculty instructional practices and percep- tions regarding student library skills. Only after such a study has been completed can bibliographic instruction librarians have a clearer picture of the variables that affect faculty opinions of library skills instruction.

\section{REFERENCES AND NOTES}

1. Patricia B. Knapp, The Monteith College Experiment (New York: Scarecrow, 1966), p.280.

2. University of Texas at Austin General Libraries, A Comprehensive Program of User Education for the General Libraries, the University of Texas at Austin (Austin, Tex.: Univ. of Texas at Austin, 1977).

3. The few studies include Larry L. Hardesty, "The Influence of Selected Variables on Attitudes of Classroom Instructors Toward the Undergraduate Educational Role of the Academic Library," Academic Libraries: Myths and Realities, ed. Suzanne C. Dodson and Gary L. Menges (Chicago: Association of College and Research Libraries, 1984); Rae Haws, Lorna Peterson, and Diane Shonrock, "Survey of Faculty Attitudes Towards a Basic Library Skills Course," College \& Research Libraries News 50:201-3 (March 1989); and Joy Thomas and Pat Ensor, "The University Faculty and Library Instruction," RQ 24:431-37 (Summer 1984).

4. Larry L. Hardesty and others, DePauw University Libraries Self-Study Report (ERIC Document Reproduction Service, ED 217 862, 1982), p.158-66.

5. John Lubans, Jr. and others, Program to Improve and Increase Student and Faculty Involvement in Library Use (ERIC Document Reproduction Service, ED 114 097, 1975), p.8-16, $20-24$.

6. Haws, Paterson, and Shonrock, "Survey of Faculty Attitudes," p.202.

7. Hardesty, "The Influence of Selected Variables," p.371-77.

8. Thomas and Ensor, "The University Faculty and Library Instruction," p.432.

9. Ibid.

10. Auburn University, Auburn University Bulletin (Auburn University, Ala.: Auburn University, 1989), p.11.

11. Loretta P. Hicks, "Abundance or Richness in Output," Community and Junior College Journal 50:11 (Dec./Jan. 1978-79).

12. For representative studies using the various methods of obtaining publication counts, see Diane Crane, "Scientists at Major and Minor Universities: A Study of Productivity and Recognition," American Sociological Review 32:700 (Oct. 1965); Jonathan R. Cole and Stephen Cole, Social Stratification in Science (Chicago: Univ. of Chicago Pr., 1973), p.33; Paul D. Allison and John A. Stewart, "Productivity Differences Among Scientists," American Sociological Review 39:599 (Aug. 1974); Barbara F. Reskin, "Scientific Productivity, Sex, and Location in the Institution of Science," American Journal of Sociology 83:1235 (Mar. 1978); Robert T. Blackburn, Charles E. Behymer, and David E. Hall, "Research Notes: Correlates of Faculty Publications," Sociology of Education 51:133 (Apr. 1978); J. Scott Long, "Productivity and Academic Position in the Scientific Career," American Sociological Review 43:892 (Dec. 1978); Helen S. Astin, "Factors Affecting Women's Scholarly Productivity," The Higher Education of Women: Essays in Honor of Rosemary Park, ed. Helen S. Astin and Werner Z. Hirsch (New York: Praeger, 1978), p.138; Eugene Garfield, Citation Indexing - Its Theory and Application in Science, Technology, and Humanities (New York: John Wiley \& Sons, 1979), p.16; Karin D. Knorr and others, "Individual Publication Productivity as a Social Position Effect in Academic and Industrial Research Units," Scientific Productivity: The Effectiveness of Research Groups in Six Countries, ed. Frank M. Andrews (Cambridge: Cambridge Univ. Pr., 1979), p.60; Susan W. Cameron and Robert T. Blackburn, "Sponsorship and Academic Career Success," Journal of Higher Education 52:371 (July/Aug. 1981); and Richard A. Wanner, Lionel S. Lewis, and David I. Gregorio, "Research Productivity in Academia: A Comparative Study of the Sciences, Social Sciences, and Humanities," Sociology of Education 54:242 (Oct. 1981).

13. Stephen Cole, "Age and Scientific Performance," American Journal of Sociology 84:961 (Jan. 1979); Duncan Lindsey, "Production and Citation Measures in the Sociology of Science: The Problem of Multiple Authorship," Social Studies of Science 10:146 (May 1980); and Robert M. Hayes, "Citation Statistics as a Measure of Faculty Research Productivity," Journal of Education for Librarianship 23:153 (Winter 1983), discuss the use of such counts obtained through the citation indexes. However, publication counts may be too crude a measure of productivity for evaluation of an individ- 
ual faculty member, as found by Richard J. Kroc, "Using Citation Analysis to Assess Scholarly Productivity," Educational Researcher 13:18 (June/July1984). Other problems found in the more sophisticated techniques of citation counts or citation analysis are discussed by Cole and Cole, p.25; Garfield, p.245; Lindsey, p.145; and Hayes, p.153. However, Kroc (p.21) concluded that data gathered from indexes and aggregated at the department, school, or college level may eliminate or ameliorate most of these problems.

14. University of Texas at Austin General Libraries, A Comprehensive Program of User Education, p.1.

15. Association of College and Research Libraries, Bibliographic Instruction Section, Policy and Planning Committee, Bibliographic Instruction Handbook (Chicago: American Library Association, 1979), p.13.

16. Virginia Tiefel, "Creating a Comprehensive Library User Education Plan," Academic Libraries: Myths and Realities, ed. Suzanne C. Dodson and Gary L. Menges (Chicago: Association of College and Research Libraries, 1984), p.239.

17. Texas Tech University Library, Report of the Ad Hoc User Instruction Committee (ERIC Document Reproduction Service, ED 254 234, 1984), p.56.

18. Jane I. Thesing, "Market Academic Library Bibliographic Instruction Programs: Case and Commentary," Research Strategies 3:34 (Winter 1985).

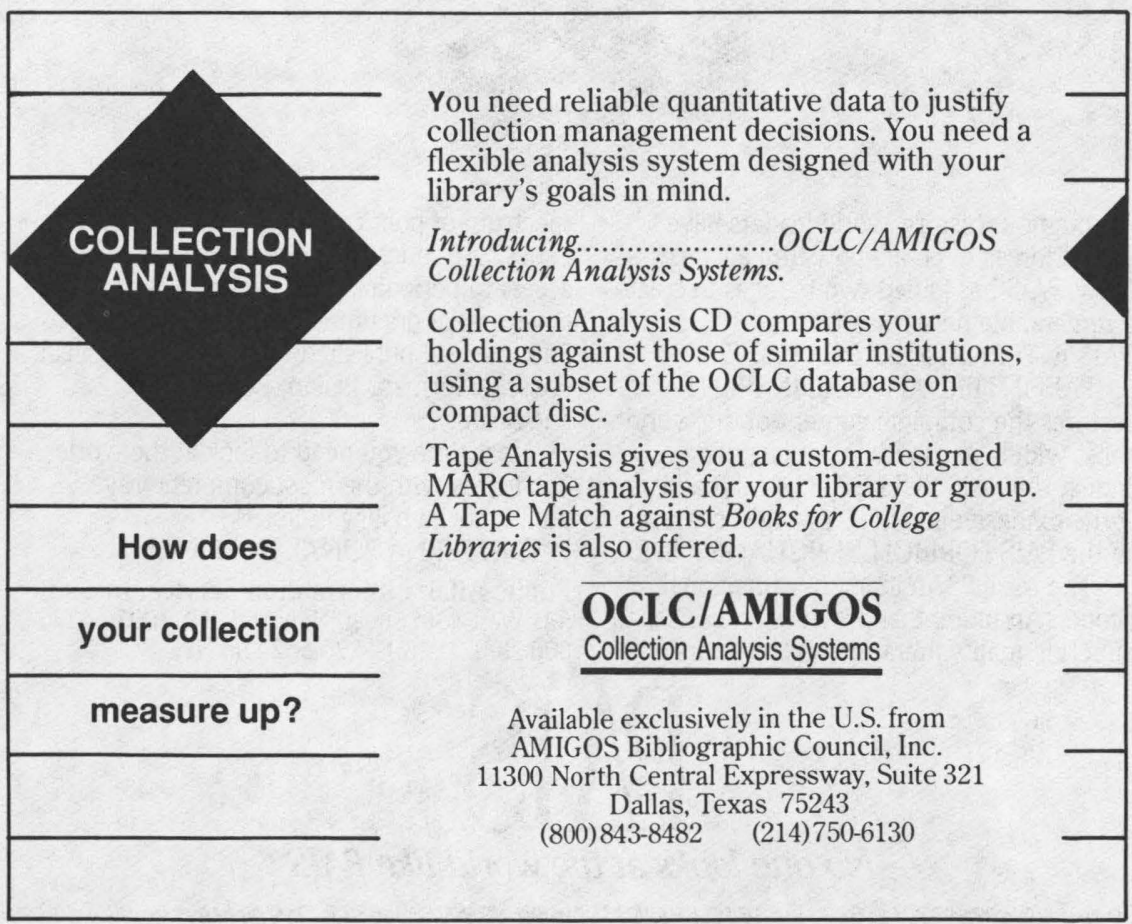




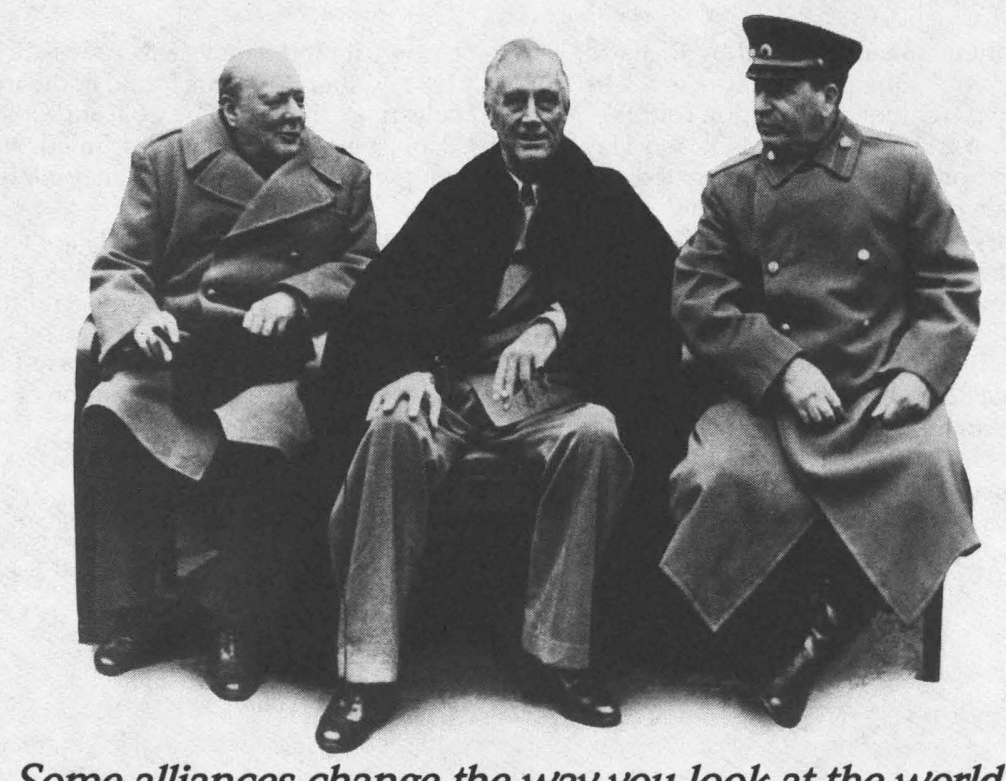

Some alliances change the way you look at the world

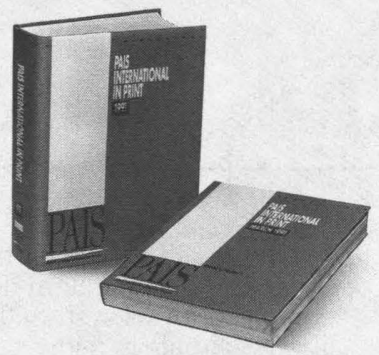

Throughout history, world leaders have joined forces to create powerful alliances. Now, PAIS has joined two indexes to create a remarkable new research tool PAIS INTERNATIONAL IN PRINT.

PAIS INTERNATIONAL IN PRINT features the complete content of the world's most widely used public/social policy index, the PAIS BULLETIN. And it adds to it the extensive foreign language coverage of the PAIS FOREIGN LANGUAGE INDEX.

The result? An index of exceptional scope. An index that provides references to superior-quality literature on the entire spectrum of political, economic, and social issues. An index that offers single-source access to periodical articles, journals, government documents, and other hard-tofind material published worldwide in English, French, German, Italian, Portuguese, and Spanish.

Next time you need to look at the world, join forces with the most comprehensive public/social policy index PAIS INTERNATIONAL IN PRINT.

Public Affairs Information Service, Inc. 521 West 43rd Street, New York, NY 10036-4396 800-288-PAIS, 212-736-6629 (in NY)

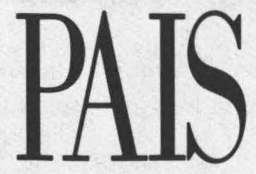

\section{No one looks at the world like PAIS}

